\title{
Analysis of the Minimum Required Coefficient of Sliding Friction at Brachistochronic Motion of a Nonholonomic Mechanical System
}

\author{
Radoslav D. Radulovic \\ Teaching Assistant \\ University of Belgrade \\ Faculty of Mechanical Engineering
}

\section{Aleksandar M. Obradovic \\ Full Professor \\ University of Belgrade \\ Faculty of Mechanical Engineering \\ Bojan M. Jeremic \\ PhD student \\ University of Belgrade \\ Faculty of Mechanical Engineering}

The paper analyzes the problem of brachistochronic motion of a nonholonomic mechanical system, using an example of a simple car model. The system moves between two default positions at an unaltered value of the mechanical energy during motion. Differential equations of motion, containing the reaction of nonholonomic constraints and control forces, are obtained on the basis of general theorems of dynamics. Here, this is more appropriate than some other methods of analytical mechanics applied to nonholonomic systems, where the provision of a subsequent physical interpretation of the multipliers of constraints is required to solve this problem. By the appropriate choice of the parameters of state as simple a task of optimal control as possible is obtained in this case, which is solved by the application of the Pontryagin maximum principle. Numerical solution of the two-point boundary value problem is obtained by the method of shooting. Based on the thus acquired brachistochronic motion, the active control forces are determined as well as the reaction of constraints. Using the Coulomb laws of friction sliding, the minimum value of the coefficient of friction is determined to avoid car skidding at the points of contact with the ground.

Keywords: Brachistochrone, Nonholonomic mechanical system,

Pontryagin's maximum principle, Coulomb friction, Optimal control.

\section{INTRODUCTION}

As is well known the classical brachistochrone problem was proposed by Johann Bernoulli in 1696 for the case of a particle moving in a vertical plane under the influence of its own gravity in a homogeneous field of gravity. Much later, the generalization of the classical brachistochrone problem was carried out within the calculus of variations [1] and [2]. A detailed review of literature related to the problems of brachistochronic motion can be found in [3] and [7]. The problems considered in the present paper involve a review of references on the Bernoulli's case of the classical brachistochrone extended to the system of rigid bodies. Paper [4] considers the Bernoulli's brachistochrone problem extended to the multibody system in the form of a closed kinematic chain without external constraints. Paper [5] considers a special case of the multibody system whose motion is limited by external constraints.

The brachistochronic motion of a multibody system in a stationary field of potential forces, and Coulomb friction, for a special case, was solved in [6] where it has been shown that there is a complete analogy between the brachistochronic motion of a mechanical system with 2-DOF, whose metric tensor is constant, and the brachistochronic motion of a particle acted on

Received: June 2013, Accepted: November 2013

Correspondence to: Radoslav Radulovic

Faculty of Mechanical Engineering,

Kraljice Marije 16, 11120 Belgrade 35, Serbia

E-mail: rradulovic@mas.bg.ac.rs

doi:10.5937/fmet1403199R

(C) Faculty of Mechanical Engineering, Belgrade. All rights reserved by the forces of viscous and Coulomb friction.

Considerations of the brachistochronic motion of a nonholonomic rheonomic mechanical system acted upon not only by control forces but also by both potential and non-potential forces can be found in [7]. The results obtained in [6] were extended in [8], where the brachistochronic motion of a mechanical system with unilateral constraints was considered.

This paper, using the example of a nonholonomic mechanical system with limited reactions of constraints, presents the procedure of creating the differential equations of motion where both reactions of nonholonomic constraints and control forces figure, based on the general theorems of dynamics [9]. Applying the general theorems of dynamics, one obtains, on one hand, more suitable relations in determining the reactions of constraints and control forces, while, on the other hand, physical interpretation of the multipliers of constraints is unnecessary as in the case of applying some other equations of analytical mechanics that refer to nonholonomic mechanical systems [10]. This paper also provides the procedure for solving brachistochronic motion of a nonholonomic mechanical system in a plane at the steady value of mechanical energy during motion, when initial and end positions are specified [14].

The formulated brachistochrone problem, with a corresponding choice of the quantities of state, was solved, in this case, as the simplest problem of optimal control by applying the Pontryagin maximum principle [11] and [12]. Simultaneously, control forces were also determined so as to realize the brachistochronic motion. 
The Coulomb laws of sliding friction were the basis for specifying the minimum required value of the coefficient of sliding friction, so that the mechanical system moves in accordance with the nonholonomic bilateral constraints. Thus determined value of the coefficient of sliding friction prevents the occurrence of the system slipping during the entire motion.

The numerical procedure for solving the two-point boundary value problem is based on the shooting method [13]. Also, estimates are provided for the intervals of parameters' values being determined.

\section{DESCRIPTION OF A NONHOLONOMIC SYSTEM MODEL}

In order to generate differential equations of motion of a nonholonomic mechanical system, using the example of a simplified vehicle model (see Fig. 1.), taken completely from [10], it is necessary first to introduce two Cartesian reference coordinate systems: the stationary coordinate system $O \xi \eta \zeta$, whose coordinate plane $O \xi \eta$ coincides with the horizontal plane of vehicle motion, and a movable coordinate system Axyz, which is rigidly attached to the vehicle body, so that the coordinate plane $A x y$ coincides with the plane $O \xi \eta$.

The axis of the movable coordinate system $A x$ is defined by the direction of a normal to the axis of the vehicle rear axle and point $C$, where $C \in A x$. Point $C$ represents the center of mass of the vehicle body, while point $A$ is the center of mass of the front axle, and $\overline{B C}=l_{2}$ and $\overline{C A}=l_{1}$ are given. Unit vectors of the movable coordinate system axes are $\vec{i}, \vec{j}$, and $\vec{k}$, respectively. A simplified vehicle model consists of a vehicle body of mass $M_{1}$, and a front axle of mass $M_{2}$, where moments of inertia are known $J_{1}$ and $J_{2}$ around the main central axes of inertia perpendicular to the plane Axy, respectively, having in mind that is $J_{1} \gg J_{2}$. The mass of rear axle and the mass of wheels are disregarded. The vehicle configuration relative to the system $O \xi \eta$ is defined by a set of Lagrangian coordinates $\left(q^{1}, q^{2}, q^{3}, q^{4}\right), \quad$ where $\quad q^{1}=\xi_{B} \quad$ and $q^{2}=\eta_{B}$ are Cartesian coordinates of the point $B$, $q^{3}=\varphi$ is the angle between the axis $O \xi$ and axis $A x$, while $q^{4}=\theta$ is the angle between the axis $A y$ and the vehicle front axle axis.

Further analysis refers to the case when point $A$ cannot move in the direction of the front axle axis, while point $B$ of the vehicle cannot move in the direction of the rear axle axis (lateral slipping of the front and rear axle is prevented). Due to the imposition of constraints to the motion, there occur horizontal reactions $\vec{R}_{A}=-R_{A} \sin \theta \vec{i}+R_{A} \cos \theta \vec{j}$ and $\vec{R}_{B}=R_{B} \vec{j}$, respectively. Such vehicle motion is limited by two ideal independent nonholonomic constraints

$$
\begin{aligned}
& -\dot{\xi}_{B} \sin \varphi+\dot{\eta}_{B} \cos \varphi=0, \\
& -\dot{\xi}_{A} \sin (\varphi+\theta)+\dot{\eta}_{A} \cos (\varphi+\theta)=0 .
\end{aligned}
$$

The consequence of the imposed constraints to the vehicle motion is that velocity $\vec{V}$ of the point $B$ has the direction of the axis $A x$, so that relations (1) can be expressed in the following form

$$
\dot{\xi}_{B}=V \cos \varphi, \quad \dot{\eta}_{B}=V \sin \varphi, \quad \dot{\varphi}=\frac{V}{l} \tan \theta,
$$

where $V=\vec{V} \cdot \vec{i}$ and $l=l_{1}+l_{2}$.

During motion, the vehicle is acted on by the control force $\vec{F}_{1}=\vec{F}_{1}(t)$ along the axis $A x$, as well as by the drag, proportinate to the first degree of the velocity of point $C$, with the coefficient of proportionality $k_{2}$, where $\vec{F}_{2}=-k_{2} \vec{V}_{C}$. During motion, the vehicle front axle is acted on by the control moment $L_{1}=L_{1}(t)$, around the vertical axis perpendicular to the plane of motion, the resistance moment $L_{2}$, proportionate to the relative angular velocity of axle rotation, where $L_{2}=k_{1} \dot{\theta}$, and the resistance moment $L_{3}$, proportionate to the relative angle of the front axle rotation around the vertical axis, where $L_{3}=k_{3} \theta$.

Now, the differential equations of vehicle motion, based on the theory of change in momentum and moment of momentum for a movable axis that passes through point $B$ and is perpendicular to the plane of motion [9], have the form

$$
\frac{d \vec{K}}{d t}=\vec{F}_{R}^{s}, \quad \frac{d \vec{L}_{B}}{d t}+\vec{V}_{B} \times \vec{K}=\vec{M}_{B}^{s},
$$

that is

$$
\begin{aligned}
& M\left[\dot{V}-\left(l_{2}+\frac{M_{2}}{M} l_{1}\right) \dot{\varphi}^{2}\right]=F_{1}-k_{2} V-R_{A} \sin \theta, \\
& M\left[\dot{\varphi} V+\left(l_{2}+\frac{M_{2}}{M} l_{1}\right) \ddot{\varphi}\right]=R_{A} \cos \theta+R_{B}-k_{2} l_{2} \dot{\varphi}, \\
& J^{*} \ddot{\varphi}+M\left(l_{2}+\frac{M_{2}}{M} l_{1}\right) \dot{\varphi} V=R_{A} l \cos \theta-k_{2} l_{2}^{2} \dot{\varphi},
\end{aligned}
$$

where $M=M_{1}+M_{2}, J \cong J_{1}\left(J_{1}>J_{2}\right)$ and $J^{*}=M_{1} l_{2}^{2}+M_{2} l^{2}+J$. The vectors of vehicle angular velocity and angular acceleration are $\vec{\omega}=\dot{\varphi} \vec{k}$ and $\vec{\varepsilon}=\ddot{\varphi} \vec{k}$, respectively.

The differential equation of vehicle front axle rotation around the axis that passes through point $A$, and is perpendicular to the plane of motion, has the form

$$
J_{2}(\ddot{\varphi}+\ddot{\theta})=L_{1}-k_{1} \dot{\theta}-k_{3} \theta
$$

Solving the system of equations (4) and (5), the reactions of nonholonomic constraints are obtained, as well as the control force and control moment, so as to realize the brachistochronic motion, in function of 
introduced quantitities of state and corresponding derivatives

$$
\begin{aligned}
& R_{A}=\frac{1}{l \cos \theta}\left[J^{*} \ddot{\varphi}+\left(M l_{2}+M_{2} l_{1}\right) \dot{\varphi} V+k_{2} l_{2}^{2} \dot{\varphi}\right], \\
& R_{B}=\frac{1}{l}\left[M_{1} l_{1} \dot{\varphi} V+\left(M_{1} l_{1} l_{2}-J\right) \ddot{\varphi}+k_{2} l_{1} l_{2} \dot{\varphi}\right], \\
& F_{1}(t)=M \dot{V}+k_{2} V+\frac{\tan \theta}{l}\left[J^{*} \ddot{\varphi}+k_{2} l_{2}^{2} \dot{\varphi}\right], \\
& L_{1}(t)=J_{2}(\ddot{\varphi}+\ddot{\theta})+k_{1} \dot{\theta}+k_{3} \theta .
\end{aligned}
$$

Also, during vehicle brachistochronic motion the law of the conservation of mechanical energy holds

$$
\Phi(V, \dot{\varphi})=M V^{2}+J^{*} \dot{\varphi}^{2}-2 T_{0}=0,
$$

where $T_{0}$ is vehicle kinetic energy at initial time moment $t_{0}=0$.

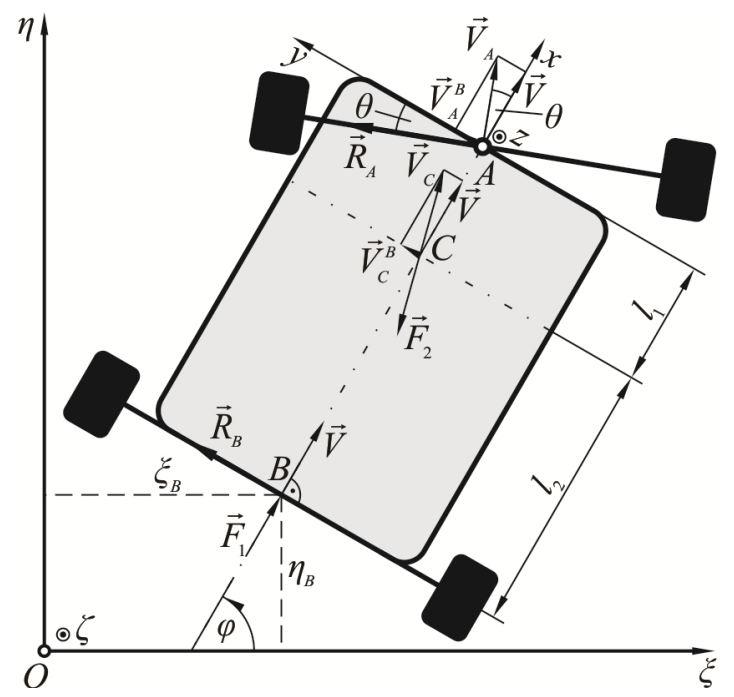

a)

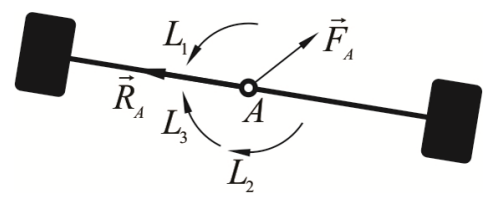

b)

Figure 1. a) Simplified vehicle model; b) front axle.

\section{BRACHISTOCHRONIC MOTION AS THE PROBLEM OF OPTIMAL CONTROL}

In this section, using the example of a simplified model of a vehicle with constrained motion, we will formulate the problem of brachistochronic motion as the problem of optimal control. The equations of state that describe the motion of the considered system in state space can be defined in the form

$$
\dot{\xi}_{B}=u_{1} \cos \varphi, \quad \dot{\eta}_{B}=u_{1} \sin \varphi, \quad \dot{\varphi}=u_{2},
$$

where controls $u_{1}$ and $u_{2}$ represent the vehicle point $B$ velocity and angular velocity vehicle, respectively.
Relative angle of the front axle rotation $\theta$ can be given on the basis of (2).

The quantities of state $\xi_{B}, \eta_{B}$ and $\varphi$ were determined at the initiation time moment

$$
t_{0}=0, \xi_{B}\left(t_{0}\right)=0, \eta_{B}\left(t_{0}\right)=0, \varphi\left(t_{0}\right)=0
$$

while quantities of state $\xi_{B}, \eta_{B}$ and $\varphi$ at the vehicle final time moment

$$
t=t_{f}, \xi_{B}\left(t_{f}\right)=a, \eta_{B}\left(t_{f}\right)=b, \varphi\left(t_{f}\right)=\varphi_{f} .
$$

The brachistochrone problem of vehicle motion, described by differential equations (8), consists in determining the controls $u_{1}$ and $u_{2}$, as well as their corresponding quantities of state $\xi_{B}, \eta_{B}$ and $\varphi$, so that the vehicle starting from the initial state (9) moves into the final state (10), with unchanged value of mechanical energy (7), in a minimum time. This can be expressed in the form of condition, so that the functional

$$
I=\int_{t_{0}}^{t_{f}} d t
$$

in the interval $\left[t_{0}, t_{f}\right]$ has a minimum value.

In order to solve the problem of optimal control, formulated using the Pontryagin maximum principle [11] and [12], we will create Pontryagin's function in the form as follows

$$
H=\lambda_{0}+\lambda_{\xi} u_{1} \cos \varphi+\lambda_{\eta} u_{1} \sin \varphi+\lambda_{\varphi} u_{2}+\mu \Phi\left(u_{1}, u_{2}\right)
$$

where $\lambda_{0}=$ const. $\leq 0, \lambda_{\xi}, \lambda_{\eta}$ and $\lambda_{\varphi}$ are coordinates of conjugate vector, where it can be taken that $\lambda_{0}=-1$, while $\mu$ is a multiplier corresponding to (7). Based on Pontryagin's function (12), the conjugate system of differential equations is

$$
\dot{\lambda}_{\xi}=0, \dot{\lambda}_{\eta}=0, \dot{\lambda}_{\varphi}=u_{1}\left(\lambda_{\xi} \sin \varphi-\lambda_{\eta} \cos \varphi\right) .
$$

If controls belong to an open set, as in this case, the conditions for determining optimal control can be expressed in the form

$$
\left(\frac{\partial H}{\partial u_{i}}\right)_{\mathbf{u}^{o p t}}=0,\left(\frac{\partial^{2} H}{\partial u_{i} \partial u_{j}}\right)_{\boldsymbol{u}^{o p t}} u_{i} u_{j} \leq 0, i, j=1,2,3 \text {. (14) }
$$

Applying the Theorem 1 [11], it follows directly that the value of Pontryagin's function on the optimal trajectory equals zero, for $\forall t \in\left[t_{0}, t_{f}\right]$

$-1+\lambda_{\xi} u_{1} \cos \varphi+\lambda_{\eta} u_{1} \sin \varphi+\lambda_{\varphi} u_{2}+\mu \Phi\left(u_{1}, u_{2}\right)=0$,

having in mind, based on (13), that $\lambda_{\xi}=$ const. and $\lambda_{\eta}=$ const.

Now, based on (14) and (15), we obtain the value of a multiplier $\mu$, as well as the control functions in the following form 


$$
\begin{aligned}
& \mu=-\frac{1}{4 T_{0}}, u_{1}=\frac{2 T_{0}}{M}\left(\lambda_{\xi} \cos \varphi+\lambda_{\eta} \sin \varphi\right), \\
& u_{2}=\frac{2 T_{0}}{J^{*}} \lambda_{\varphi} .
\end{aligned}
$$

Based on relation (15) determined at the initial time moment, and based on (9), (14) and (16), we obtain the value of coordinate $\lambda_{\varphi}$ at the initial time moment

$$
\lambda_{\varphi}\left(t_{0}\right)= \pm \sqrt{J^{*}\left(\frac{1}{2 T_{0}}-\frac{\lambda_{\xi}^{2}}{M}\right)} .
$$

Determining the reactions of constraints and control forces (6), relations (16) are obtained by differentiation with respect to time (w.r.t.), having in mind (13). The shooting method was used in numerical procedure for solving the corresponding two-point boundary value problem, based on (8), (9), (10), (13), (16) and (17), [13].

The application of shooting method requires specified intervals of the values of parameters to be determined. The global estimates for the interval of value of the conjugate vector coordinate $\lambda_{\xi}$ can be given on the basis of (13), (14) and (16)

$$
-\sqrt{\frac{M}{2 T_{0}}} \leq \lambda_{\xi} \leq \sqrt{\frac{M}{2 T_{0}}} .
$$

Shooting consists in determining the unknown coordinates of conjugate vector $\lambda_{\xi}$ and $\lambda_{\eta}$, having in mind (16) and (17), as well as a minimum required time $t_{f}$, so that the vehicle starting from initial state (9) moves into the final state (10).

The two-point boundary value problem was solved for the following values of parameters

$$
\begin{aligned}
& T_{0}=1000 \frac{\mathrm{kgm}^{2}}{\mathrm{~s}^{2}}, \varphi\left(t_{f}\right)=\frac{\pi}{2} \mathrm{rad}, \\
& M_{1}=1000 \mathrm{~kg}, \\
& M_{2}=110 \mathrm{~kg}, J_{1}=1500 \mathrm{kgm}^{2}, \\
& J_{2}=30 \mathrm{kgm}^{2}, \\
& l_{1}=0.75 \mathrm{~m}, l_{2}=1.65 \mathrm{~m}, a=5 \mathrm{~m}, b=5 \mathrm{~m}, \\
& k_{1}=0.5 \mathrm{Nsm}, k_{2}=100 \frac{\mathrm{Ns}}{\mathrm{m}}, k_{3}=100 \mathrm{Nm} .
\end{aligned}
$$

The estimates for the intervals of values of the conjugate vector coordinates $\lambda_{\xi}$ and $\lambda_{\eta}$ can be given on the basis of (16), (18) and (19)

$$
\begin{aligned}
& -0.745 \leq \lambda_{\xi} \leq 0745, \\
& -0.745 \leq \lambda_{\eta} \leq 0.745 .
\end{aligned}
$$

In accordance with (11), the time of the vehicle brachistochronic motion, as well as the conjugate vector coordinates, for the given values of the system parameters (19), are $t_{f}=6.2223 \mathrm{~s}, \lambda_{\xi}=0.5124$ and $\lambda_{\eta}=0.5124$.
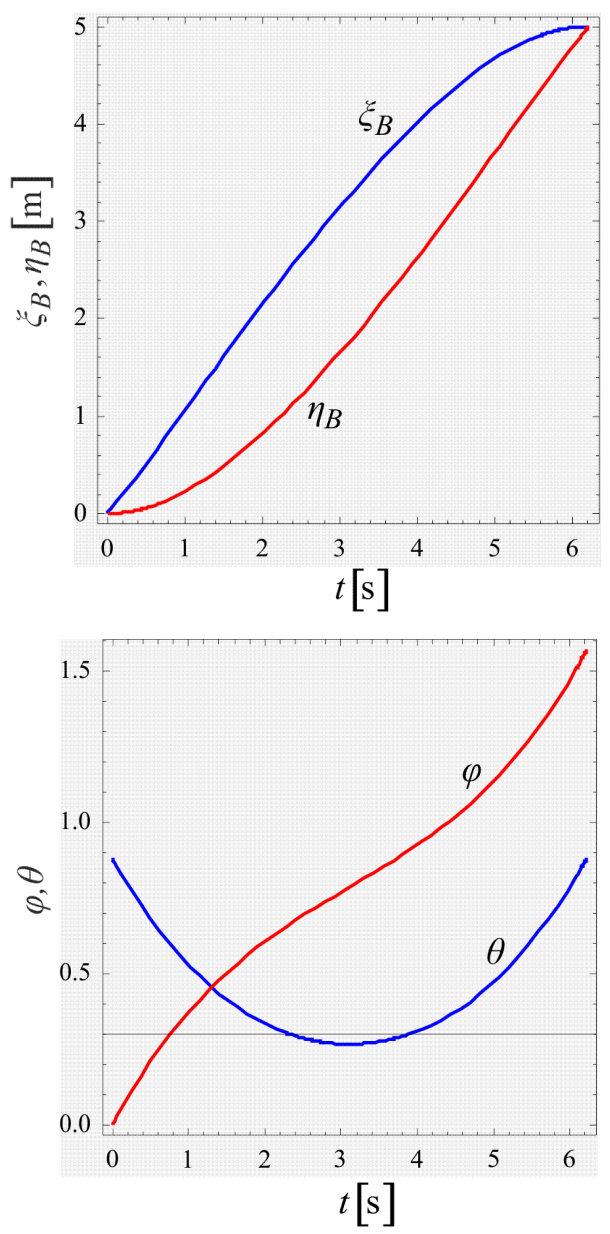

Figure 2. Quantities of state $\xi_{B}(t), \eta_{B}(t), \varphi(t)$ and $\theta(t)$.
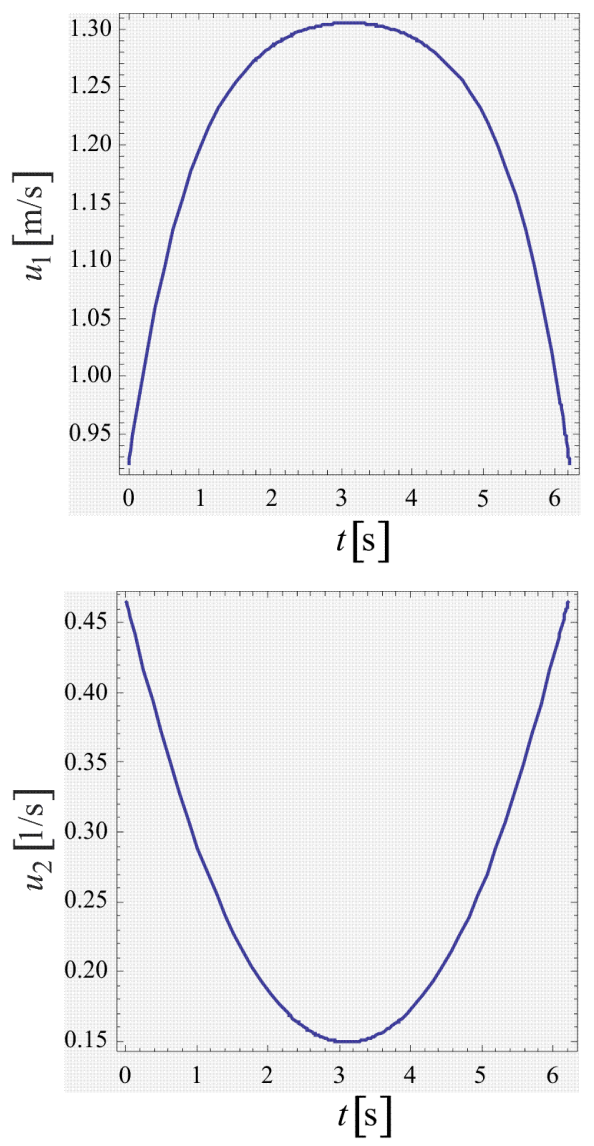

Figure 3. Optimal controls $u_{1}(t)$ and $u_{2}(t)$. 

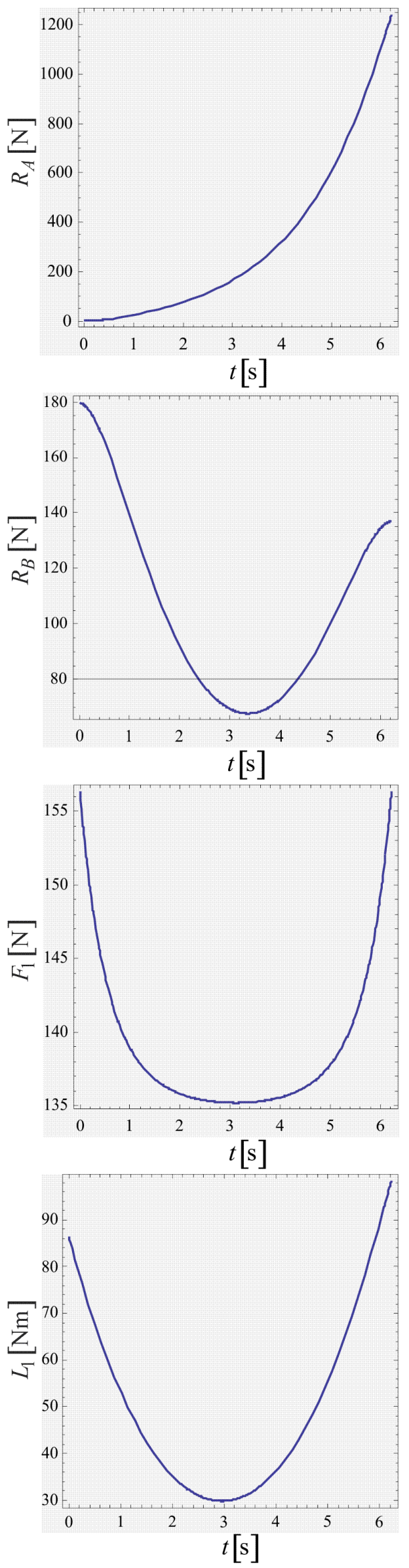

Figure 4. Reactions of constraints $R_{A}(t), R_{B}(t)$, and control forces $F_{1}(t), L_{1}(t)$.

\section{CONDITIONS FOR CONSTRAINTS BASED ON COULOMB SLIDING FRICTION}

Differential equations of vehicle motion (4) were obtained assuming that equations of nonholonomic bilateral constraints (1) are satisfied at any time moment. Having this in mind, the necessary dynamic conditions for realizing such motion [10], and based on the Coulomb laws of sliding friction, are

$$
\sqrt{R_{B}^{2}+F_{1}^{2}} \leq N_{1} \mu_{1}^{*}, \quad\left|R_{A}\right| \leq N_{2} \mu_{2}^{*},
$$

where $\mu_{1}^{*}$ and $\mu_{2}^{*}$ are the coefficients of sliding friction between rear and front wheels, respectively, and stationary surface. Normal reactions of rear and front axle stationary surface are $N_{1}=3065.6 \mathrm{~N}$ and $N_{2}=7823.5 \mathrm{~N}$, respectively.

The diagrams below, based on above considerations, show the laws of minimum required values of the coefficients of sliding friction $\mu_{1}^{*}$ and $\mu_{2}^{*}$ in function of time.

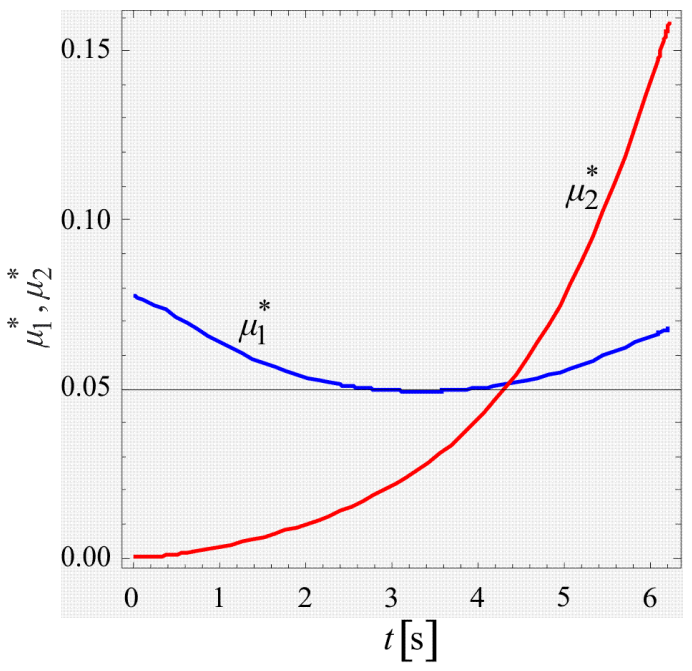

Figure 5. Diagrams $\mu_{1}^{*}=\mu_{1}^{*}(\boldsymbol{t})$ and $\mu_{2}^{*}=\mu_{2}^{*}(\boldsymbol{t})$.

Based on above considerations, it can be inferred (see Fig. 5.) that a minimum required value of the coefficient of sliding friction, between stationary surface and vehicle wheels, is $\mu^{*} \geq 0.16$.

\section{CONCLUSIONS}

In this paper, using the example of a simplified vehicle model (see Fig. 1.) with constrained motion (1), we have presented the procedure of generating differential equations of motion (4) and (5), based on the general theorems of dynamics [9].

The formulated brachistochrone problem, with a corresponding choice of the equations of state (8), was solved, in this case, as the simplest problem of optimal control. Applying the Pontryagin maximum principle [11] and [12], the problem of optimal control was solved (see Fig. 2. and Fig. 3.), with a given estimate of the interval of conjugate vector coordinates (18).

Thereafter, the reactions of constraints were determined, as well as the control forces for realizing 
the brachistochronic motion, as shown in Fig. 4. The performed numerical procedure for solving the twopoint boundary value problem is based on the shooting method [13].

Applying the Coulomb laws of sliding friction, minimum required values for the coefficient of sliding friction were determined, so as to prevent slipping of both vehicle rear and front axle, as presented in Fig. 5.

Authors consider that results obtained in this paper can be extended to the case when the coefficients of sliding friction are below minimum required values. In that case, as well as in the case when control forces are constrained, the problem of optimal control becomes considerably more complex, which will be the subject of future studies.

\section{ACKNOWLEDGMENT}

Authors gratefully acknowledge the support of Ministry of Education, Science and Technological Development of the Republic of Serbia under the project ON 17400 and TR 35006.

\section{REFERENCES}

[1] Elsgolc, L.E.: Calculus of Variations, Pergamon Press, Oxford, 1963.

[2] Gelfand, I.M. and Fomin, S.V.: Calculus of Variations, Prentice, Hall, Englewood Cliffs, 1964.

[3] Šalinić, S.: Contribution to the brachistochrone problem with Coulomb friction, Acta Mech., 208(1-2), pp. 97-115, 2009.

[4] Čović, V. and Lukačević, M.: Extension of the Bernoulli's case of a brachistochronic motion to the multibody system in the form of a closed kinematic chain, Facta Univ., Mech. Autom. Control Robot., 2(9), pp. 973-982, 1999.

[5] Čović, V. and Vesković, M.: Extension of the Bernoulli's case of brachistochronic motion to the multibody system having the form of a kinematic chain with external constraints, Eur.J. Mech. A, Solids 21, pp. 347-354, 2002.

[6] Čović, V. and Vesković, M.: Brachistochronic motion of a multibody system with Coulomb friction, Eur. J. Mech. A, Solids 28(9), pp. 882890, 2009.

[7] Obradović, A., Čović, V., Vesković, M. and Dražić, M.: Brachistochronic motion of a nonholonomic rheonomic mechanical system, Acta Mech., 214 (34), pp. 291-304, 2010.

[8] Šalinić, S., Obradović, A. and Mitrović, Z.: On the brachistochronic motion of mechanical system with unilateral constraints, Mechanics Research Communications, 45, pp. 1-6, 2012.

[9] Pars, L.A.: Treatise on analytical dynamics, Heinemann, London, 1968.

[10] Soltakhanov, Sh. Kh., Yushkov, M.P. and Zegzhda, S.A.: Mechanics of non-holonomic systems, Berlin: Springer-Verlag, 2009.

[11] Pontryagin, L.S., Boltyanskii, V.G., Gamkrelidze, R.V. and Mishchenko, E.F.: The Mathematical Theory of Optimal Processes, Wiley, New Jersey, 1962.

[12] Leitmann, G.: An introduction to optimal control, McGraw-Hill, New York, 1966.

[13] Stoer, J. and Bulirsch, J.: Introduction to Numerical Analysis, second ed. Springer, New York and London, 1993.

\section{АНАЛИЗА МИНИМАЛНО ПОТРЕБНОГ \\ КОЕФИЦИЈЕНТА ТРЕЊА КЛИЗАЊА ПРИ БРАХИСТОХРОНОМ КРЕТАҢУ НЕХОЛОНОМНОГ МЕХАНИЧКОГ СИСТЕМА}

\section{Радослав Радуловић, Александар Обрадовић, Бојан Јеремић}

Анализира се проблем брахистохроног кретања механичког система на примеру једног упрошћеног модела возила. Систем се креће између два задата положаја при неизмењеној вредности механичке енергије у току кретања. Диференцијалне једначине кретања, у којима фигуришу реакције нехолономних веза и управљачке силе, добијају се на основу општих теорема динамике. Овде је то подесније уместо неких других метода аналитичке механике примењених на нехолономне системе, у којима је неопходно дати накнадно физичко тумачење множитеља веза да би се овај проблем решио. Подесним избором величина стања, добија се, најпростији могућ у овом случају, задатак оптималног управљања, који се решава применом Понтрјагиновог принципа максимума. Нумеричко решавање двотачкастог граничног проблема врши се методом шутинга. На основу тако добијеног брахистохроног кретања одређују се активне управљачке силе, а уједно и реакције веза. Користећи Кулонове законе трења клизања, одређује се минимално потребна вредност коефицијента трења клизања, да не би дошло до проклизавања возила у тачкама контакта са подлогом. 